\title{
Timing Fungicide Applications for Managing Sclerotinia Stem Rot of Potato
}

Dennis A. Johnson, Department of Plant Pathology, Washington State University, Pullman 99164-6430; and Zahi K. Atallah, Department of Plant Pathology, University of Wisconsin, Madison 53706

\begin{abstract}
Johnson, D. A., and Atallah, Z. K. 2006. Timing fungicide applications for managing Sclerotinia stem rot of potato. Plant Dis. 90:755-758.

Fungicides were applied to potato foliage at row closure (between rows) and at full bloom of primary inflorescences to control Sclerotinia stem rot during replicated trials in 2003, 2004, and 2005. Application at row closure followed labeled recommendations from manufacturers. Incidence of Sclerotinia stem rot did not vary significantly among fungicides when full labeled rates of thiophanate-methyl, fluazinam, and boscalid were applied at full bloom of primary inflorescences. Incidence of Sclerotinia stem rot was significantly less when fungicides thiophanatemethyl, fluazinam, or boscalid were applied to potato foliage at full bloom of primary inflorescences than at row closure or when fungicides were not applied in 2004 and 2005, and when thiophanate-methyl or fluazinam was applied to potato foliage at full bloom of primary inflorescences than at row closure or when fungicides were not applied in 2003. Mean percentage of control for the fungicides combined, relative to the nontreated control, was 43,48 , and $20 \%$ in 2003, 2004, and 2005, respectively, when application was made at row closure; whereas, it was 77,83 , and $80 \%$ in 2003, 2004, and 2005, respectively, when application was at full bloom of primary inflorescences. Mean disease incidences of infected stem were significantly less when fluazinam was applied at $100 \%$ bloom of primary inflorescences than at $20 \%$ drop of blossoms from primary inflorescences in 2004 and 2005. In summary, control of Sclerotinia stem rot was significantly better when fungicides were applied at full bloom of primary inflorescences than at row closure during all 3 years of the study.
\end{abstract}

Additional keywords: white mold, chemical control, fungicide application timing

Sclerotinia sclerotiorum (Lib) de Bary, the cause of Sclerotinia stem rot or white mold on potato, is an ascomycetous fungus of global distribution that infects more than 400 species in 75 plant families (5). In the Columbia Basin of south central Washington and northeastern Oregon, common cultivated crops susceptible to $S$. sclerotiorum include potato, bean, pea, carrot, cucurbits, and Brassica spp. (12). Increased disease incidences have been associated with cultivar architecture and morphology, high crop density, close row width, continuous plant surface wetness, and excess nitrogen fertilization in potato and other crops $(5,6,10,11,13)$.

Prior to 2003, Sclerotinia stem rot was not satisfactorily managed in potatoes in the Columbia Basin of Washington and Oregon. Frequent sprinkler irrigation applications from center-pivot systems, high plant density, and dense crop canopies promoted prolonged plant surface wetness and high humidity and subsequent disease development $(6,13)$. One to three fungicide applications were usually made in an at-

Corresponding author: D. A. Johnson

E-mail: dajohn@wsu.edu

Accepted for publication 18 January 2006.

DOI: 10.1094/PD-90-0755

(C) 2006 The American Phytopathological Society tempt to control Sclerotinia stem rot on potato. The fungicides dichloran (Botran 5F; Gowan, Yuma, AZ), iprodione (Rovral 4F; Bayer CropScience, Research Triangle Park, NC), and quintozene (pentachloronitrobenzene) (Blocker 4F; AMVAC Chemical Corp., Newport Beach, CA) were registered and used. Initial application was made just prior to or at row closure according to labeled instructions and recommendations from Extension (12). Applications prior to row closure were made to achieve stem coverage within the potato canopy. Growers often deemed control inadequate. The reason for the poor control was not known.

S. sclerotiorum in the Columbia Basin shows a high level of haplotype diversity compared with other locations (4). The fungus was found to undergo outcrossing sexual recombination in that region, offsetting the previously described strict homothallic nature of the fungus (4). However, no differences in sensitivity to any of the registered fungicides were observed among isolates collected from various locations in the Columbia Basin (4).

Ascospores of S. sclerotiorum are incapable of direct infection of intact green leaves and stem tissues of potato and other crops, but they colonize flowers and other senescing tissues using them as energy sources to infect green tissues (1-3,7). Airborne ascospores are deposited on open potato blossoms attached to the canopy
(3). Infested flowers fall on stems and the ground, and fungal mycelia rapidly colonize the blossoms when humidity is high in the plant canopy. Stems or leaves contacting colonized blossoms then acquire the pathogen. Flowers and other senescing tissue colonized by ascospores were found to cause the vast majority of observed lesions as opposed to infections near the soil line initiated by mycelium from soilborne sclerotia. Flower removal before blossom drop or fungicide application at full or $100 \%$ bloom of primary inflorescences drastically reduced disease incidence (3).

A potato shoot is composed of a main stem and branches. It can produce one or more cymose inflorescences over time. The main stem of a potato shoot terminates in an inflorescence, which is called the primary inflorescence. Shoot growth continues by apical branching, and each branch terminates in an inflorescence of the corresponding order. Inflorescences on higher orders of branching are younger and flower later (15). Indeterminate potato cultivars produce flowers over a longer time period than determinate cultivars.

Fungicide application at full bloom of primary inflorescences has not been directly compared to application at row closure for control of Sclerotinia stem rot on potato. The primary purpose of this study was to evaluate the effectiveness of fungicide applications for control of Sclerotinia stem rot at row closure and at full bloom of primary inflorescences.

\section{MATERIALS AND METHODS}

Trials were conducted in commercial potato fields on a sandy-loam north of Pasco, WA, in 2003, 2004, and 2005. Different fields were used each year. Fields were 53 ha in size and irrigated with center-pivot systems. Certified potato seed was planted at 23 to $25 \mathrm{~cm}$ spacing within rows and at $86 \mathrm{~cm}$ spacing between rows in mid-March of each year. Cultivars were Shepody in 2003 and 2005, and Ranger Russet in 2004. Shepody is a determinate cultivar and Ranger Russet is an indeterminate cultivar. Both cultivars produce dense canopies and are susceptible to $S$. sclerotiorum. Relatively high disease incidences of Sclerotinia stem rot occur in fields of both cultivars. Plot size was three rows $(2.6 \mathrm{~m})$ wide and $9.1 \mathrm{~m}$ long. The grower irrigated, managed weeds and insects, and cultured the crop according to standard commercial practices. However, the grower did not apply fungicides for 
control of Sclerotinia stem rot to the section of the field containing the experimental plots.

Fungicides thiophanate-methyl (Topsin M 70 WP; Cerexagri, Inc., King of Prussia, $\mathrm{PA})$ at $1.176 \mathrm{~kg}$ a.i./ha, fluazinam (Omega 500F; Syngenta Crop Protection, Greensboro, NC) at $0.280 \mathrm{~kg}$ a.i./ha, and boscalid (Endura; BASF Corporation, Research Triangle Park, NC) at $0.336 \mathrm{~kg}$ a.i./ha were used. In 2003, single applications of thiophanate-methyl and fluazinam were made at row closure on 30 May, single applications of thiophanate-methyl, fluazinam, and boscalid were made at $10 \%$ bloom of primary inflorescences on 2 June and at $100 \%$ bloom of primary inflorescences on 5 June, and a single application of boscalid mary inflorescences on 9 June (Table 1). In 2004 , single applications of thiophanatemethyl, fluazinam, and boscalid were made at row closure on 2 June, at $100 \%$ bloom of primary inflorescences on 8 June, and at $20 \%$ blossom drop from primary inflorescences on 15 June. In 2005, was made at $10 \%$ blossom drop from pri-

single applications of thiophanate-methyl, fluazinam, and boscalid were made at row closure on 24 May, $10 \%$ bloom of primary inflorescences on 27 May, $70 \%$ bloom of primary inflorescences on 31 May, $100 \%$ bloom of primary inflorescences on 3 June, and a single application of fluazinam was made at $20 \%$ blossom drop from primary inflorescences on 8 June. The fungicides and fungicide application timings were arranged in a randomized complete block design with four replicates. Fungicides were applied using a $\mathrm{CO}_{2}$ pressurized sprayer at a rate of 281 liters of water/ha at $210 \mathrm{kPa}$, with a ConeJet hollow cone nozzle, TXVS-18 (R\&D Sprayers Inc., Opelousas, LA).

Row closure was considered to be when leaves began overlapping between plant rows of the entire plot area. Percent bloom was determined by assessing the percentage of flower blooms that were fully open on at least $95 \%$ of the primary inflorescences in the plot area. Percent drop of flower blossoms from primary inflorescences was assessed by determining the percentage of

Table 1. Number of potato stems with lesions caused by Sclerotinia sclerotiorum when one to three fungicides were applied to potato foliage at one of six crop development stages near Pasco, WA, in 2003 to 2005

\begin{tabular}{|c|c|c|c|}
\hline \multirow[b]{2}{*}{ Time of application/fungicide ${ }^{x}$} & \multicolumn{3}{|c|}{ Number of infected stems ${ }^{w}$} \\
\hline & $2003^{y}$ & $2004^{z}$ & $2005^{y}$ \\
\hline Control & $44 \mathrm{aA}$ & $29 \mathrm{aA}$ & $59 \mathrm{aA}$ \\
\hline $\begin{array}{l}\text { Row closure } \\
\text { Thiophanate-methyl } \\
\text { Fluazinam } \\
\text { Boscalid } \\
\text { Mean }\end{array}$ & $\begin{array}{l}30 \text { May } \\
30 \mathrm{~b} \\
20 \mathrm{c} \\
\ldots \\
25 \mathrm{~B}\end{array}$ & $\begin{array}{l}2 \text { June } \\
16 \mathrm{~b} \\
14 \mathrm{~b} \\
15 \mathrm{~b} \\
15 \mathrm{~B}\end{array}$ & $\begin{array}{l}24 \text { May } \\
54 \mathrm{ab} \\
46 \mathrm{bc} \\
41 \mathrm{~cd} \\
47 \mathrm{~B}\end{array}$ \\
\hline $\begin{array}{l}10 \% \text { bloom of } 1^{\circ} \text { inflorescences } \\
\text { Thiophanate-methyl } \\
\text { Fluazinam } \\
\text { Boscalid } \\
\text { Mean }\end{array}$ & $\begin{array}{l}2 \text { June } \\
15 \mathrm{~cd} \\
9 \mathrm{de} \\
5 \mathrm{e} \\
10 \mathrm{C}\end{array}$ & $\begin{array}{l}\cdots \\
\cdots \\
\cdots\end{array}$ & $\begin{array}{l}27 \text { May } \\
40 \mathrm{~cd} \\
32 \mathrm{de} \\
19 \mathrm{fg} \\
30 \mathrm{C}\end{array}$ \\
\hline $\begin{array}{l}70 \% \text { bloom of } 1^{\circ} \text { inflorescences } \\
\text { Thiophanate-methyl } \\
\text { Fluazinam } \\
\text { Boscalid } \\
\text { Mean }\end{array}$ & $\begin{array}{l}\ldots \\
\ldots \\
\ldots\end{array}$ & $\begin{array}{l}\ldots \\
\ldots \\
\ldots\end{array}$ & $\begin{array}{l}31 \text { May } \\
17 \mathrm{~g} \\
14 \mathrm{gh} \\
6 \mathrm{~h} \\
12 \mathrm{D}\end{array}$ \\
\hline $\begin{array}{l}100 \% \text { bloom of } 1^{\circ} \text { inflorescence } \\
\text { Thiophanate-methyl } \\
\text { Fluazinam } \\
\text { Boscalid } \\
\text { Mean }\end{array}$ & $\begin{array}{l}5 \text { June } \\
10 \mathrm{de} \\
11 \mathrm{de} \\
6 \mathrm{e} \\
10 \mathrm{C}\end{array}$ & $\begin{array}{l}8 \text { June } \\
6 \mathrm{c} \\
3 \mathrm{c} \\
6 \mathrm{c} \\
5 \mathrm{C}\end{array}$ & $\begin{array}{l}3 \text { June } \\
12 \mathrm{gh} \\
12 \mathrm{gh} \\
12 \mathrm{gh} \\
12 \mathrm{D}\end{array}$ \\
\hline $\begin{array}{l}10 \% \text { drop of } 1^{\circ} \text { inflorescence } \\
\text { Boscalid } \\
\text { Mean }\end{array}$ & $\begin{array}{l}9 \text { June } \\
10 \mathrm{de} \\
10 \mathrm{C}\end{array}$ & $\cdots$ & $\cdots$ \\
\hline $\begin{array}{l}20 \% \text { drop of } 1^{\circ} \text { inflorescence } \\
\text { Thiophanate-methyl } \\
\text { Fluazinam } \\
\text { Boscalid } \\
\text { Mean }\end{array}$ & $\begin{array}{l}\ldots \\
\ldots \\
\ldots \\
\ldots\end{array}$ & $\begin{array}{l}15 \text { June } \\
14 \mathrm{~b} \\
16 \mathrm{~b} \\
16 \mathrm{~b} \\
15 \mathrm{~B}\end{array}$ & $\begin{array}{l}8 \text { June } \\
\ldots \\
27 \text { ef } \\
\ldots \\
27 \mathrm{C}\end{array}$ \\
\hline
\end{tabular}

${ }^{w}$ Number of infected stems per $9.1 \mathrm{~m}$. Values are means of four replicates. Values within a column followed by the same letter are not significantly different at $\alpha=0.05$, according to Fisher's protected least significant difference test. Lowercase letters refer to individual fungicide treatments. Uppercase letters refer to means for fungicide combined within application timing. ... indicates treatment not applied.

${ }^{x}$ Fungicide rate: thiophanate-methyl (Topsin M $70 \mathrm{WP}$ ) was $1.176 \mathrm{~kg}$ a.i./ha, fluazinam (Omega 500F) was $0.280 \mathrm{~kg}$ a.i./ha, and boscalid (Endura) was $0.336 \mathrm{~kg}$ a.i./ha.

${ }^{y}$ Cultivar Shepody.

${ }^{\mathrm{z}}$ Cultivar Ranger Russet. pedicels without blossoms on at least $95 \%$ of the primary inflorescences in the plot area.

Disease incidence was assessed in the middle row of each plot by counting the number of stems with lesions 15 days after the disease was first evident in plots. Percentage of control was calculated as 100 [(mean number of stems with lesions from fungicide treatment/mean number of stems with lesions from nontreated control) $x$ 100].

Disease incidence data for infected stems were analyzed by a two-way factorial analysis of variance in a randomized complete block design using PROC GLM in SAS (SAS Institute Inc., Cary, NC). Factors were fungicide treatment and timing of fungicide application with a nontreated control. Data from each of the 3 years were analyzed separately. Fisher's protected least significant difference at $\alpha=$ 0.05 was used to compare treatment means. Interactions may not have been detected by the SAS program because the fungicide treatments were not balanced within timings of application. Single degree of freedom contrasts at $\alpha=0.05$ were also used to test differences between fungicides within each timing of fungicide application.

\section{RESULTS}

Disease symptoms on stems presumably from airborne inoculum were evident on 17 June in 2003, on 22 June in 2004, and on 23 June in 2005 . This was 17 days after row closure and 12 days after full bloom of primary inflorescences in 2003, 20 days after closure and 17 days after full bloom of primary inflorescences in 2004, and 30 days after row closure and 20 days after full bloom of primary inflorescences in 2005. Mean disease incidence on the nontreated control was 44, 29, and 59 infected stems per $9.1 \mathrm{~m}$ in 2003, 2004, and 2005, respectively (Table 1).

Fungicide treatments and timings of fungicide application both varied significantly $(P<0.05)$ each of the 3 years. Significant interactions between fungicide treatment and timing of fungicide application were not detected each year $(P>$ $0.05)$. However, efficacy of fungicides varied in 2003 and 2005 depending on application timing. Incidence of Sclerotinia stem rot was less $(P<0.05)$ when plots were treated with fluazinam than with thiophanate-methyl at row closure in 2003, and with boscalid than with thiophanate-methyl at $10 \%$ bloom of primary inflorescences in 2003; and with boscalid than with thiophanate-methyl at row closure, $10 \%$ bloom, and $70 \%$ bloom of primary inflorescences in 2005 (Table 1). Disease incidence did not vary $(P>0.05)$ among the three fungicides when applied at $100 \%$ bloom of primary inflorescences in 2003, 2004, and 2005 (Table 1) or when applied at row closure and $20 \%$ 
drop of primary flower clusters in 2004 (Table 1).

Incidence of Sclerotinia stem rot was less $(P<0.05)$ when either thiophanatemethyl or fluazinam was applied to potato foliage at full bloom of primary inflorescences than when applied at row closure or not applied in 2003, and when either thiophanate-methyl, fluazinam, or boscalid was applied to foliage at full bloom of primary inflorescences than when applied at row closure or not applied in 2004 and 2005 (Table 1). Mean percentage of control for the fungicides combined, relative to the nontreated control, was 43,48 , and $20 \%$ in 2003, 2004, and 2005, respectively, when application was made at row closure; whereas, it was 77,83 , and $80 \%$, in 2003 , 2004 , and 2005, respectively, when application was at full bloom of primary inflorescences.

Mean incidence of Sclerotinia stem rot was less $(P<0.05)$ when fluazinam was applied at $100 \%$ bloom of primary inflorescences than at $20 \%$ blossom drop in 2004 and 2005 (Table 1). Mean incidence of disease was less $(P<0.05)$ when thiophanate-methyl, fluazinam, or boscalid were applied either at $10 \%$ bloom, $70 \%$ bloom, or $10 \%$ drop than when applications were made at row closure (Table 1). Mean disease incidence for the fungicides combined did not differ $(P>0.05)$ when applications were at $10 \%$ bloom, $100 \%$ bloom, and $10 \%$ drop of primary inflorescences in 2003 (Table 1).

\section{DISCUSSION}

Control of Sclerotinia stem rot was significantly improved when fungicides were applied at full bloom of primary inflorescences compared with applications at row closure. Contaminated flower blossoms served as a bridge for infection, and fungicides applied when flowers were exposed to airborne ascospores subsequently reduced infections on stems. Similar observations for timing of fungicide application were made when bean flowers were protected with benomyl at full bloom, which prevented white mold development even under optimal environmental conditions $(2,14)$. Applications of benomyl made after full bloom on beans failed to provide effective stem rot control because flowers had already acquired the inoculum $(9,10)$. A significant reduction of Sclerotinia stem rot was observed in this study when applications were made after full bloom of primary inflorescences (20\% blossom drop) compared with the nontreated control. This can be explained by the extended time period that potato blossoms were produced and dropped, but the level of control at $20 \%$ blossom drop was still less than when fungicide application was made at full bloom of primary inflorescences.

Inoculum of $S$. sclerotiorum is abundant at full bloom of primary inflorescences in many potato fields in the Columbia Basin
(3). Immature apothecia generally first emerge at or shortly after row closure in potato and neighboring fields planted to other crops in the Columbia Basin, and the greatest numbers of ascospores of $S$. sclerotiorum were captured after row closure and about a week before and continuing a few days after full bloom of primary inflorescences in a previous study (3). A hundred percent of the blossoms collected at full bloom of primary inflorescences from potato plants in 8 of 10 fields were contaminated with $S$. sclerotiorum, and initial stem infections originating from airborne ascospores and the subsequent mycelial growth on an organic substrate were not observed until after blossom drop in the previous study (3). Furthermore, senescent or dead potato foliar tissues generally were not on the ground to serve as a substrate for mycelial growth of $S$. sclerotiorum until after row closure and at full bloom of primary inflorescence. Fungicide application at full bloom of primary inflorescences and before blossom drop was then theorized to be an effective application timing for the control of Sclerotinia stem rot in a previous study that quantified numbers of deposited ascospores, blossom contamination, and disease development over time (3).

A difference in application timing of a few days made a difference in degree of control. Fungicides applied at row closure did not cover the flower blossoms because blossoms were absent at that time, and fungicides applied at $20 \%$ blossom drop were too late to effectively prevent stem infections from infested blossoms. Data in 2003 and 2005 indicated that the window for effective applications was somewhat wider than just at $100 \%$ bloom, but data in 2004 and 2005 demonstrated that the window width for most effective control truncated before $20 \%$ drop of primary flower inflorescences.

A protective cover of fungicide on potato stems and on potential substrates for saprophytic growth of $S$. sclerotiorum are both likely needed for effective chemical control. Fungicides applied at row closure are possibly washed from stems and partially degraded before inoculum on colonized blossoms and other substrates is present; whereas, applications at full bloom of primary inflorescences are made just before infection would otherwise occur from dropping contaminated blossoms. We have observed colonization periods (time from inoculation with colonized blossoms to initial stem lesions on potato stems) of 3 days in greenhouse experiments (unpublished data). This is consistent with the rapid development of lesions that is often noted soon after contaminated blossoms drop in a humid potato canopy. In light of the current findings, we recommend amending fungicide labels and disease management recommendations for control of Sclerotinia stem rot of potato to take into consideration the data presented in this study and that initial application be made at full bloom of primary inflorescences and not at row closure.

The fungicides used in this study, when applied at full bloom of primary inflorescences, did not vary in efficacy, and all three effectively reduced Sclerotinia stem rot; whereas, thiophanate-methyl was generally less effective than either fluazinam or boscalid in reducing number of stems with lesions when applied at row closure and $10 \%$ bloom of primary inflorescences in 2003 and 2005 (Table 1). Boscalid, which has systemic translaminar redistribution properties, was more effective than the other two contact fungicides when applied at $10 \%$ bloom of primary inflorescences in 2005.

Sclerotia of $S$. sclerotiorum in soil can infect nearby stems by the soil surface before blossom fall, and foliar fungicides tested in this study would not be expected to prevent these infections from occurring. This is because the inoculum exists in or on the soil, and soil around the lower stems prevents contact of the fungicide with the stem.

Sufficient disease developed in plots during the 3 years to evaluate fungicide application timing. The reason for the difference in mean disease severity among the nontreated controls for the 3 years is not completely known, but differences in disease incidence among years are commonly observed. Ranger Russet (indeterminate) was used in 2004, the year with the least amount of disease, and Shepody (determinate) the other 2 years. Both cultivars produce dense crop canopies, and severe white mold develops in nonprotected, commercial fields of both cultivars. The structure of a dry edible bean canopy was shown to affect white mold incidence; whereas growth habit (determinate or indeterminate) of bean cultivars did not exclusively influence the incidence of infection (13).

As expected, the time period between row closure and $100 \%$ bloom of primary inflorescences varied in this study. It ranged from 6 to 9 days in the 3 years in this study and from 5 to 10 days over 10 fields during 2 years in a previous study (3). Initial disease symptoms of Sclerotinia stem rot from airborne inoculum were not observed until after full bloom of primary inflorescences in this and a previous study (3), and fungicides applied before full bloom of primary inflorescences are exposed to weathering and potential wash off of foliage for a longer time period before potential infection than fungicide applications made at full bloom.

Fungicides for control of Sclerotinia stem rot are applied by chemigation in the Columbia Basin. A backpack sprayer was used to apply fungicides so that application timing treatments and replicates could be in close proximity to best suit the purpose of this study. The relative differences 
among application timings found in this study should be the same when applying the same materials by chemigation. Furthermore, similar differences in disease control as demonstrated in this study have been observed in commercial fields when fungicides for Sclerotinia stem rot control were applied by chemigation at full bloom of primary inflorescences compared with application at row closure (unpublished data).

Significant yield reductions in potato due to $S$. sclerotiorum have not been demonstrated in the Pacific Northwest (8), possibly because the disease was not adequately controlled in plots used for a noninfected standard. The effect of Sclerotinia stem rot on yield of potato should now be evaluated using effective fungicides applied at an effective timing.

Improvements in management of Sclerotinia stem rot occurred in commercial potato fields in the Columbia Basin during the 2003 through 2005 growing seasons when growers, based on our previous work (3), applied a fungicide at full bloom of primary inflorescences. These observations are in reference to seasons before 2003, when initial application was made at row closure. Usually one fungicide application was sufficient for satisfactory control when application was at full blossom of primary inflorescences in the 2003 through 2005 seasons; whereas, two and three applica- tions often did not give satisfactory control when applications were initiated at row closure before 2003. Thiophanate-methyl has been used for control of white mold on bean for a number of years. The fungicide fluazinam was registered for potato for the 2003 season, and boscalid was registered for potato for 2004 in the Columbia Basin, and these products have aided in effectiveness of control. However, timing of fungicide application is particularly crucial for effective control.

\section{ACKNOWLEDGMENTS}

We thank Washington State Potato Commission for supporting funds, Thomas F. Cummings for technical assistance, and D. A. Inglis, J. S. Miller, and P. B. Hamm for critical reviews of the manuscript. Plant Pathology Number Series 0388, Department of Plant Pathology, College of Agriculture and Home Economics Research Center, Project 0678, Washington State University, Pullman.

\section{LITERATURE CITED}

1. Abawi, G. S., and Grogan, R. G. 1974. Ascospores of Whetzelinia sclerotiorum as primary inoculum causing white mold of beans in New York. (Abstr.) Phytopathology 64:578.

2. Abawi, G. S., Polach, F. J., and Molin, W. T. 1975. Infection by ascospores of Whetzelinia sclerotiorum. Phytopathology 65:673-678.

3. Atallah, Z. K., and Johnson, D. A. 2004. Development of Sclerotinia stem rot in potato fields in south-central Washington. Plant Dis. 88:419-423.

4. Atallah, Z. K., Larget, B., Chen, X., and Johnson, D. A. 2004. High genetic diversity, phenotypic uniformity, and evidence of outcrossing in Sclerotinia sclerotiorum in the Columbia Basin of Washington State. Phytopathology 94:737-742.

5. Boland, G. J., and Hall, R. 1988. Epidemiology of Sclerotinia stem rot of soybean in Ontario. Phytopathology 78:1241-1245.

6. Grau, C. R., and Radke, V. L. 1984. Effects of cultivars and cultural practices on Sclerotinia stem rot of soybeans. Plant Dis. 68:56-58.

7. Keary, M. A. 1939. A study of certain species of the genus Sclerotinia. Ann. Appl. Biol. 26:227-246.

8. Miller, T. D., and Miller, J. S. 2001. Sclerotinia white mold of potato. Pages 185-186 in: Proc. 2001 Idaho Winter Commodity Schools, Aberdeen, ID.

9. Morton, J. G., and Hall, R. 1989. Factors determining the efficacy of chemical control of white mold in white bean. Can. J. Plant Pathol. 11:297-302.

10. Natti, J. J. 1971. Epidemiology and control of bean white mold. Phytopathology 61:699-674.

11. Partyka, R. E., and Mai, W. F. 1962. Effects of environment and some chemicals on Sclerotinia sclerotiorum in laboratory and potato field. Phytopathology 52:766-770.

12. Pscheidt, J. W., and Ocamb, C. M., eds. 2002 Pacific Northwest Plant Disease Management Handbook. Oregon State University, Corvallis.

13. Schwartz, H. F., Steadman, J. R., and Coyne, D. P. 1978. Influence of Phaseolus vulgaris blossoming characteristics and canopy structure upon reaction to Sclerotinia sclerotiorum. Phytopathology 68:465-470.

14. Steadman, J. R. 1983. White mold - A serious yield-limiting disease of bean. Plant Dis. 67:346-350.

15. Struik, P C., and Wiersema, S. G. 1999. Seed Potato Technology. Wageningen Pers, Wageningen, The Netherlands. 